\title{
Educational actions in human communication health: telehealth contributions in primary care
}

\author{
Gabriela Guedes de Sá Leitão(1) \\ Tatiana de Paula Santana da Silva ${ }^{(1)}$ \\ Maria Luiza Lopes Timóteo de Lima ${ }^{(1)}$ \\ Mirella Rodigues ${ }^{(1)}$ \\ Cynthia Maria Barboza do Nascimento(1)
}

(1) Universidade Federal de Pernambuco, Recife, Pernambuco - Brasil.

Conflict of interests: Nonexistent

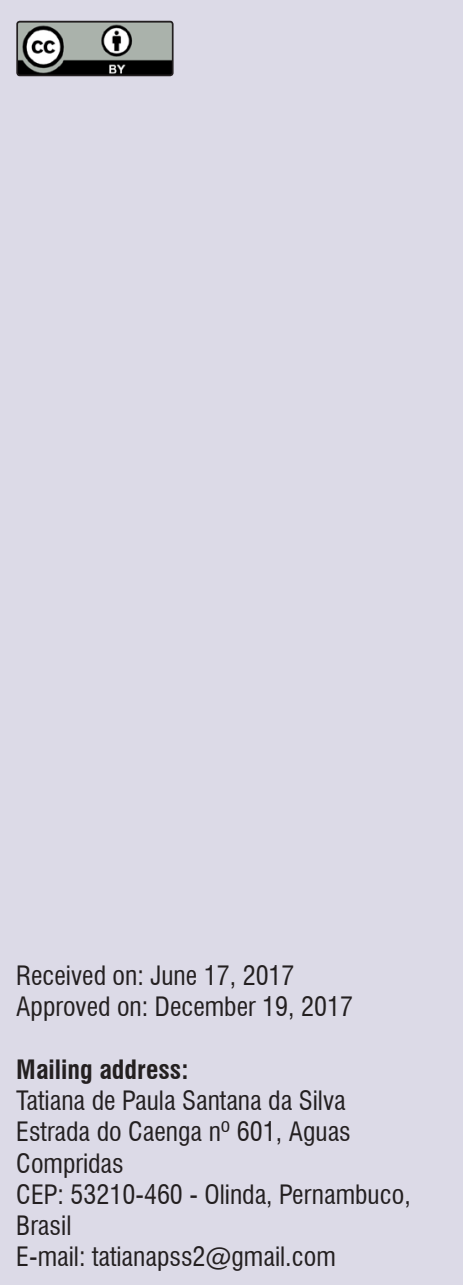

\section{ABSTRACT}

Objective: to characterize educational actions related to human communication health produced at the Tele-Health Center for health professionals in primary care.

Methods: a cross-sectional study was conducted at the Tele-Health Center at the Federal University of Pernambuco Clinical Hospital. Educational actions produced by tele-consultants between 2008 and 2014 linked to the health of human communication were considered. Data collection was conducted in two phases. In the first phase, the data were explored and educational actions were selected based on the title and the relationship with human communication. In the second phase, each action was observed and evaluated for content. The data were analyzed using descriptive statistics.

Results: a few educational actions related to human communication health were concentrated in 2014. Throughout the period analyzed, the actions were restricted to the field of language and concentrated on the education issue as well as the strategic area of child and adolescent health. The most frequent occupational category among the tele-consultants was nursing.

Conclusion: a small number of educational actions addressing the health of human communication was produced and the participation of speech therapists remains incipient.

Keywords: Speech, Language and Hearing Sciences; Telemedicine; Primary Health Care; Education, Distance; Education, Continuing 


\section{INTRODUCTION}

Family Health is operationalized through the implementation of reference teams, composed of professionals from different areas, including: doctor, nurse, nursing technicians and community health workers. These teams aim to develop health promotion and disease prevention, rehabilitation, recovery and maintenance of health ${ }^{1}$.

According to the need to respond in full to the population's health problems, in 2008, the Ministry of Health created the Family Health Support Center (FHSC), which aims to ensure the continuity and completeness of care, supporting the Family Health Strategy in network services. This consists of professionals from different areas of knowledge, among them Speech, language and hearing terapist ${ }^{2}$.

The primary health care $(\mathrm{PHC})$ has enabled numerous advances related to the health of the population; however, some challenges are pointed out, such as the heterogeneity of the quality of care provided by family health; and the difficulty of responding comprehensively and broadly to the recent and old health problems that characterize the Brazilian population $^{3}$

One of the strategies developed to qualify the teams corresponds to the development and expansion of actions related to Continuing Education in Health. The Ministry of Health in an attempt to strengthen PHC through family health, in 2007, established the National Telehealth Program with the objective of developing health care to support actions, specially lifelong learning, contributing to change in working practices ${ }^{4,5}$.

In 2011, the Brazilian Telehealth Program has been redefined and expanded by the Ministry of Health, being named as "Programa Nacional Telessaúde Brasil Redes", Brazilian National Telehealth Network Program, now with the objective of supporting the consolidation of Health Care Networks defined by the PHC. The provision of telehealth services enables the integration of health professionals teams with universities contributing to improve the quality of care in primary care. In order to provide teleconsulting, telediagnostic, second opinion training and tele-education services.

The activities of tele-education match the educational practices (classes, courses and seminars) held by health professional and various areas mediated by information and communication technology tools; among them, the most common are web conferencing and video conferencing ${ }^{6}$.
Speech, language and hearing sciences, as a field of knowledge has undergone significant changes in recent years, specifically aimed at their entry into new areas such as the field of public health. From this perspective, stands out mainly the expansion of attention to the work object, from communication disorders to the health of human communication?.

In an attempt to develop the Speech, language and hearing practice in the perspective of integral health, the Federal Council of Speech, language and hearing sciences through the Resolution No. 427/2013 CFFa defines the practice of telehealth as a profession through the use of information and communication technologies, in order to increase quality, equity and efficiency of services and professional education provided by these means ${ }^{8}$.

Whereas telepractice of speech, language and hearing sciences is a strategy that can bring together professionals and qualify work in health, overcoming geographical barriers and reaching different contexts through the use of information and communication technologies, it is necessary to invest in studies exploring the telehealth tool and present their potentials and challenges.

Thus, this study aims to characterize the educational activities related to health of human communication produced in the core of telehealth for professionals inserted into the PHC.

\section{METHODS}

The study is part of a research project approved by the Ethics Committee of the Federal University of Pernambuco under the protocol number 113359/2015. This is a secondary data, cross-sectional survey with the Tele-Health Center at the Federal University of Pernambuco Clinical Hospital (HC-UFPE-NUTES), which is dedicated to teach and research new information and communication technologies applied to health, bringing many benefits to society.

The NUTES-HC was created in 2003 and is financially sponsored by the Ministry of Health $(\mathrm{MOH})$. In 2007, joined the Brazilian National Telehealth Network Program. This network consists of telehealth centers that offer Telecare services, Tele management and Tele-education for telehealth sites, especially in PHC units ${ }^{9}$.

In 2015, in order to contribute to the strengthening of the work process of professionals working in NASF, it was incorporated into the core project "Telefonoaudiologia in Primary Health Care", having as 
guiding axis actions of tele-education focused on the subject of human communication health in different life cycles ${ }^{10}$.

All educational activities produced by teleconsultants and made available in the Virtual Learning Environment for partner municipalities were considered objects of the study.

Only the actions related to the theme "Human communication health", available from 2008 until 2014, were considered. The activities that had as their purpose the promotion of services and / or products, restricted to certain interest groups, and were not directed to PHC professionals, were not included in the study.

To better understand the data collection process, it was decided to organize the study into two phases, as described below:

Phase 1: Research in the virtual learning environment: at this stage, the search for information in the Virtual Learning Environment was held. Keywords used were "communication" and "speech" in isolation and combined with the aid of Boolean operator "AND". Educational actions by title and / or summary, that had a relationship with health of human communication and fitted the criteria were included.

Phase 2: Analysis of educational activities: previous included actions by title and abstract were observed and analyzed regarding to content. At this stage, the following information was extracted from the educational practices:

- Title of the action;

- Year - period in which the action was created.

- Topic - classified as: management and planning; education and intervention;

- Strategic area - classified according to the nine areas of NASF:health of the child / adolescent and young; mental health; rehabilitation / older adult health; food and nutrition; social service; women's health; pharmaceutical care; physical activity / body practices; complementary and integrative practices ${ }^{11}$;

- Speech, language and hearing sciences - classified as: Audiology, Dysphagia, Language, Orofacial Motricity, Public Health and Voice;

- Teleconsultant / author professional category of the educational activities - classified as: Speech, language and hearing professional or other areas;

In the process of information analysis, the researchers chose to create a database with the aid of Microsoft Excel 2016. The information was tabulated and analyzed with descriptive statistics, and the findings summarized and presented in the form of graphs and tables.

\section{RESULTS}

Among the 934 educational activities found in the environment, it was observed that 41 of these were linked to the theme health of human communication, which corresponds to $4.4 \%$ of the total. The 41 actions found were submitted by 35 teleconsultants, and some of these have produced more than one action.

Figure 1 shows the temporal distribution of educational activities in the period of 2008-2014, showing that in 2008 were created only two actions related to the health of human communication. In 2009, there was a significant increase over the previous year, eight actions being produced. In 2010, there was a decline in the number of actions, correponding to four productions. In 2012, a small increase was identified with seven educational activities, in 2014, an increase in the number of actions held, with 12 in total, was identified. 


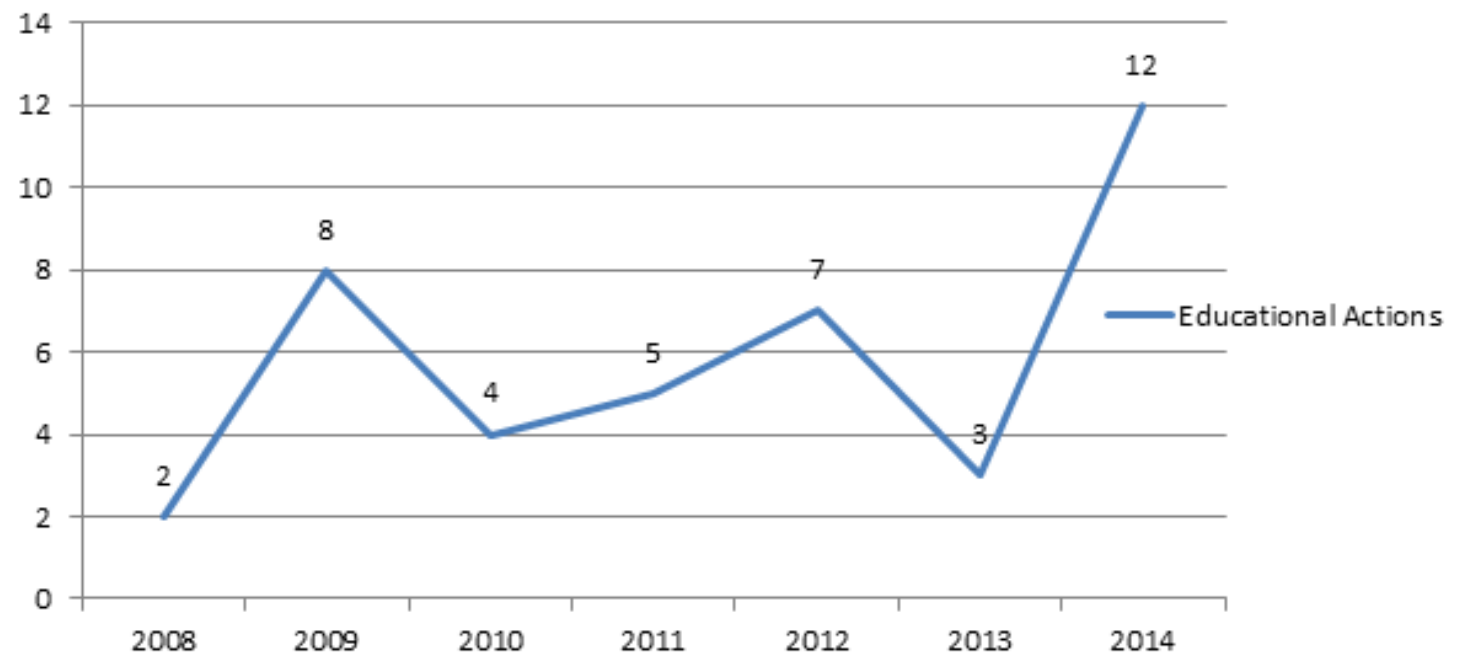

Figure 1. Quantitative distribution of educational actions related to the human communication health 2008-2014

Regarding thematic axes, it was verified that out of the 41 educational actions, 34 were related to education, six to intervention and only one fitted in management and planning (Table 1).

In relation to the distribution of educational actions by NASF strategic areas, it was found that of the 41 actions, only 36 fitted in this subject, and of these, 11 dealt with the child and adolescent health, six rehabilitation / older adult health, five in the field of food and nutrition, six in mental health field and seven in the field of social work. It is noteworthy that there were no communication health actions related to the strategic areas: women's health; pharmaceutical care; physical activity / body practices; and integrative and complementary practices (Table 1 ).

Among the areas of speech, language and hearing sciences, it was found that 25 of the produced actions were about language, followed by the areas of orofacial motricity (10), audiology (3), dysphagia (1), public health (1) and voice (1) . It is noted that in 2014, of the 12 educational activities found, 8 were in the language area (Table 1).

Among the teleconsultants, nursing was the professional category with the highest production of educational actions (13), followed by medical sciences (8), speech, language and hearing sciences (7) and psychology (3). 
Table 1. Educational actions analysis according to the thematic axes, strategic areas of the guidelines of the family health support center and great areas of the speech, language and hearing sciences thematic axes from 2008 to 2014

\begin{tabular}{ccccccccccc}
\hline \multirow{2}{*}{ Variables } & \multicolumn{9}{c}{ Year of publication of educational practice } & \multicolumn{3}{c}{ Total } \\
\cline { 2 - 10 } & $\mathbf{2 0 0 8}$ & $\mathbf{2 0 0 9}$ & $\mathbf{2 0 1 0}$ & $\mathbf{2 0 1 1}$ & $\mathbf{2 0 1 2}$ & $\mathbf{2 0 1 3}$ & $\mathbf{2 0 1 4}$ & $\mathrm{N}$ & $\%$ \\
\hline Thematic Axis & $\mathbf{2}$ & $\mathbf{8}$ & $\mathbf{4}$ & $\mathbf{5}$ & $\mathbf{7}$ & $\mathbf{3}$ & $\mathbf{1 2}$ & $\mathbf{4 1}$ & $\mathbf{1 0 0 . 0}$ \\
Management & 0 & 0 & 0 & 0 & 0 & 1 & 0 & $\mathbf{1}$ & $\mathbf{2 . 4}$ \\
Education & 2 & 7 & 3 & 5 & 5 & 1 & 11 & $\mathbf{3 4}$ & $\mathbf{8 2 . 9}$ \\
Intervention & 0 & 1 & 1 & 0 & 2 & 1 & 1 & $\mathbf{6}$ & $\mathbf{1 4 . 7}$ \\
\hline Educational actions according to strategic & $\mathbf{2}$ & $\mathbf{8}$ & $\mathbf{3}$ & $\mathbf{2}$ & $\mathbf{7}$ & $\mathbf{3}$ & $\mathbf{1 1}$ & $\mathbf{3 6}$ & $\mathbf{1 0 0 . 0}$ \\
areas of the NASF & 1 & 5 & 1 & 2 & 2 & 0 & 0 & $\mathbf{1 1}$ & $\mathbf{3 0 . 5}$ \\
Health of the child / adolescent and young & 0 & 1 & 0 & 0 & 2 & 2 & 1 & $\mathbf{6}$ & $\mathbf{1 6 . 6}$ \\
Mental health & 0 & 0 & 0 & 0 & 1 & 0 & 6 & $\mathbf{7}$ & $\mathbf{1 9 . 5}$ \\
Rehabilitation / older adult health & 1 & 0 & 2 & 0 & 1 & 0 & 1 & $\mathbf{5}$ & $\mathbf{1 3 . 9}$ \\
Food and nutrition & 0 & 2 & 0 & 0 & 1 & 1 & 3 & $\mathbf{7}$ & $\mathbf{1 9 . 5}$ \\
Social work & $\mathbf{2}$ & $\mathbf{8}$ & 4 & $\mathbf{5}$ & $\mathbf{7}$ & $\mathbf{3}$ & $\mathbf{1 2}$ & $\mathbf{4 1}$ & $\mathbf{1 0 0 . 0}$ \\
Areas of Speech, Language and Hearing & 0 & 1 & 0 & 0 & 0 & 0 & 2 & $\mathbf{3}$ & $\mathbf{7 . 4}$ \\
Sciences & 0 & 0 & 0 & 0 & 1 & 0 & 0 & $\mathbf{1}$ & $\mathbf{2 . 4}$ \\
Audiology & 2 & 6 & 4 & 1 & 2 & 2 & 8 & $\mathbf{2 5}$ & $\mathbf{6 1}$ \\
Dysphagia & 0 & 0 & 0 & 4 & 4 & 0 & 2 & $\mathbf{1 0}$ & $\mathbf{2 4 . 4}$ \\
Language & 0 & 0 & 0 & 0 & 0 & 1 & 0 & $\mathbf{1}$ & $\mathbf{2 . 4}$ \\
Orofacial motricity & 0 & 1 & 0 & 0 & 0 & 0 & 0 & $\mathbf{1}$ & $\mathbf{2 . 4}$ \\
Public health & & &
\end{tabular}

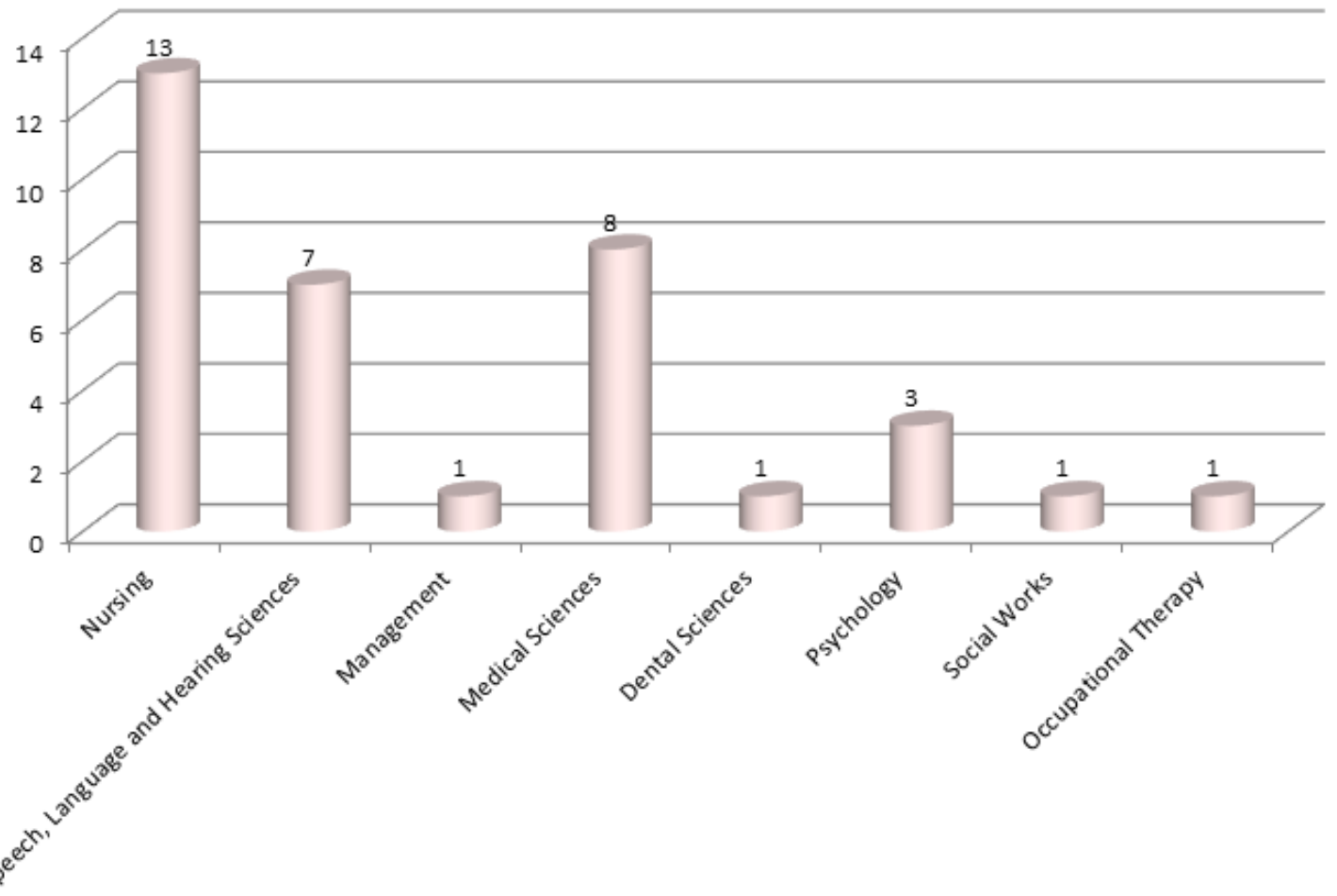

Figure 2. Tele-consult educational actions distribution related to the human communication health, by professional categories 


\section{DISCUSSION}

There was an increase in educational activities during the studied period, two in 2008 to 12 in 2014. This scenario may have been influenced by the regulation of the practice of Telehealth in Speech, language hearing sciences in 2013, which aims to contribute to training of professionals working in $\mathrm{PHC}$ through the use of technological devices (CFFa, 2013) ${ }^{8}$.

From 2008, with the creation of NASF, the role of the Speech, language and hearing therapist in PHC was institutionalized at the national level, which may also have contributed to the expansion of educational actions $^{12}$.

Moreover, the transformation of the work object of speech, language and hearing professional, which passes the communication disorder to the health of human communication ${ }^{7}$, points out the need for a new type of professional with the ability to learn and adapt to new situations, and are based in lifelong learning and contributing to the quality of health services ${ }^{13}$.

Of the three themes, education was the most discussed category in educational actions, which confirms the essence of distance educational practices, which aim to qualify the work processes of health professionals teams ${ }^{14}$. Another publication ${ }^{15-17}$ reaffirms the fact that Tele-education has been a significant healthcare / educational training and qualification plan.

Additionally, the increase in the number of practices of intervention and to promote lifelong learning is noticed, corroborating significantly with the expansion of the potential for patient rehabilitation and making decisions based on evidences ${ }^{18}$.

With regard to NASF's strategic areas, the productions focused on the health of children and adolescents were more expressive. Dias and associates ${ }^{19}$ point out that the explanation of these age cycles between the teams is of utmost importance, as well as being priority issues at the level of care by the Health Ministry, critical stages of human development, due to physical and psychoemotional fragility, necessitating a broader view of the teams on possible health risk indicators ${ }^{20}$.

The area related to the rehabilitation / integral health of older adults also stood out among the quantitative actions. This can be justified in view of the significant increase of older adults in recent decades in Brazil and the increase in life expectancy ${ }^{21}$. The findings corroborate the need to expand the work with this population, in which the speech, language and hearing therapy during this phase brings better results minimizing common changes in this life cycle ${ }^{22}$.
The strategic area of social service also obtained a considerable percentage among the educational practices, possibly due to the fact that when inserted in the context of the APS by the work developed in the Nasf teams they will return to provide specialized support to the Teams, based on integrality, interdisciplinarity and intersectoriality, in addition to demonstrating, mostly, a commitment to the mobilization and social participation of users. Thus it is estimated that this area is increasingly addressed within the context of permanet education ${ }^{23}$.

With regard to large areas of speech, language and hearing sciences, it was observed that the production of educational actions are concentrated in the area of language. This result may be due to the high prevalence of language disorders, speech and hearing registered in population-based study, approximately $10 \%$ of the population reported some type of complaint in speech and hearing, being $6.5 \%$ of complaints related to changes in speech, language and swallowing, and $3.6 \%$ specifically related to hearing ${ }^{24}$. In addition, there is a continuous growth of the overall scientific production in speech language and hearing sciences, highlighting the area of language ${ }^{15,18,25}$.

It is believed that the large number of educational activities related to the theme of language and orofacial motricity also be because of the large number of actions for the priority areas of NASF such as child, adolescent and older adults health. In these stages of life, are determining factors for normal language development, feeding and nutrition and communicationrelated changes due to aging ${ }^{26}$.

Already Spinardi and associates ${ }^{27}$, point out that the audiology area is one of the most discussed in the production of knowledge of telephonoaudiology, possibly because most studies relate the remote assistance tool in cases of cochlear implant. However, in this study, audiology area was less expressive, with only three of all the objects produced in the period.

The above authors point out in their study that there are some services provided by telehealth in the areas of speech, language and hearing sciences as: teleconsultation actions in the areas of orofacial motor skills,as well as the creation and delivery of software "SoundHelper" used to treat aphasic patients in the language area. Thus it can be considered that the development of these actions compared to the results of this study reaffirms the broad possibility of creating actions related to various areas of speech therapy. 
In this study, there was a significant presence of nursing in the production of educational activities focused on health of human communication, compared with other professional categories. Godoy, Guimarães and $\mathrm{Assis}^{28}$ claim that the nursing interventions focused on telehealth has advanced in Brazil and, therefore, is characterized as an important strategy to drive the development of teaching and nursing care in the country and is considered one of the most remotely active professional categories under health.

The author adds that the work should be part of a integrated health care system, not replace, but rather to improve and expand existing health care services, as well as to improve access, the proper use and efficiency of health services ${ }^{28}$.

It also highlights the participation of medical sciences considerably in the development of actions. De Barros Lucena Junior and Dini ${ }^{29}$ highlight the importance of telehealth tool with regard to the care and dedication to the patient, but also to provide assistance and education services. Carneiro and associates ${ }^{30,31}$ reaffirm that telehealth has the ability to provide to isolated populations a high quality medical care by setting up an alternative resolute and quick access, within medical education.

The practice of medical sciences in telehealth can be considered as an enabling instrument of education at different levels of graduation, education and qualification of health professionals ${ }^{12}$.

Despite the actions are related to the health of human communication, it was noted the absence of speech, language and hearing professionals cooperation in the production of the actions. This aspect refers mainly to the little knowledge of programs of continuing education in health prevailing in the country, including telehealth, which still has considerable specificities such as computerization and instrumentation for its use $^{32}$. Other aspects that may have contributed to the lower share of the audiologist as teleconsultor are the potential lack of telehealth tool for the work process qualification and incipient inclusion of this category in family health through $\mathrm{NASF}^{10}$.

Silva and associates ${ }^{33}$ emphasize that the practices of distance education represent new possibilities for the capacity to intensify the training and improvement of the speech, language and hearing professional in an extended way. This reaffirms the need of the health professional of human communication to appropriate these technologies, aiming at the improvement of their work process.
There is a large collection of studies on telehealth and their actions, but there is little amount of research relating to speech therapy. Thus, further work on this subject, can enhance the use of this technology, in addition to contributing to profissional qualification ${ }^{10}$.

Limitations of the present study include the small quantitative of practices for analysis, which refers to the need to expand and disseminate ongoing educational actions, such as telehealth, to support speech, language and hearing professionals working at the PHC.

\section{CONCLUSIONS}

Educational activities related to health communication offered by the Telehealth Center of the Pernambuco Federal University Clinical Hospital are few, and are mostly produced and presented by other professional categories, and in speech, language and hearing area are focused in language. This study allowed reflecting on the need to expand and disseminate the telehealth tool as a potential practice for the qualification of speech, language and hearing professional work process that operates in the PHC.

Tele-Education emerges as an efficient strategy that is able to promote exchanges of experiences and support the professional qualification of people living in distant areas. Describing the educational actions produced from 2008 to 2014 was of great importance because it contributes to the promotion of other learning objects that arise as demands for the health of human communication.

\section{REFERENCES}

1. Rodrigues LBB, Silva PCS, Peruhype RC, Palha PF, Popolin MP, Crispim JÁ et al. Primary Health Care in the coordination of health care networks: an integrative review. Ciênc. saúde coletiva. 2014;19(2):343-52.

2. Fernandes TL, Nascimento CMB, Sousa FOS. Analyzing the functions of speech therapists of nasf in recife metropolitan region. Rev. CEFAC. 2013;15(1):153-9.

3. Miranda GMD, Mendes ACG, Silva ALA, Santos Neto PM. Family health team expansion and the more doctors program in brazilian municipalities. Trab. educ. saúde. 2017;15(1):131-45.

4. Arantes LJ, Shimizu HE, Merchán-hamann E. The benefits and challenges of the Family Health 
Strategy in Brazilian Primary Health care: a literature review. Ciênc. saúde coletiva. 2016;21(5):1499-510.

5. Brasil. Ministério da Saúde. Ministério da Saúde. Gabinete do Ministro. Portaria no 402, de 24 de fevereiro de 2010. Institui, em âmbito nacional, - Programa Telessaúde Brasil para apoio à Estratégia de Saúde da Família no Sistema Único de Saúde, institui o Programa Nacional de Bolsas do Telessaúde Brasil e dá outras providências. Diário Oficial da União Brasília: MS;2010. [Acesso em: 27 abr. 2017]. Disponível em: <http:// bvsms.saude.gov.br/bvs/saudelegis/gm/2010/ prt0402_24_02_2010.html>.

6. Brasil. Ministério da Saúde. Gabinete do Ministro. Portaria no 2.546, de 27 de outubro de 2011. Redefine e amplia o Programa Telessaúde Brasil, que passa a ser denominado Programa Nacional Telessaúde Brasil Redes (Telessaúde Brasil Redes). Brasília: Ministério da Saúde, 2011c. [Acesso em: 14 ago. 2016]. Disponível em: <http:// bvsms.saude.gov.br/bvs/saudelegis/gm/2011/ prt2546_27_10_2011.html>.

7. Lima MLLT, Vilela MBR, Silva VL. Novas Perspectivas para a Atuação na Saúde da Comunicação Humana. In: Queiroga BAM, Gomes AOC, Silva HJ (orgs). Desenvolvimento da Comunicação Humana nos Diferentes Ciclos de Vida. São Paulo: Profono; 2015.p.15-8.

8. Conselho Federal de Fonoaudiologia. Resolução n. 427, de 10 de março de 2013. Dispõe sobre a regulamentação da Telessaúde em Fonoaudiologia e dá outras providências. Diário Oficial da União. 05 mar 2013; Seção 1:158. [Acesso em 25 de abril, 2017]. Disponível em: <http://www.fonoaudiologia. org.br/legislacaoPDF/Res\%20427-2013.pdf.>

9. Dias RS, Marques AFH, Diniz PRB, Silva TAB, Cofiel L, Castro MMM et al. Telemental health in Brazil: past, present and integration into primary care. Arch Clin Psychiatry. 2015;42(2):41-4.

10. Nascimento CMBD, Lima MLLTD, Sousa FDOS, Novaes MDA, Galdino DR, Silva ÉCH et al. Telespeech therapy as a continued education strategy in primary health care in the state of Pernambuco, Brazil. Rev. CEFAC. 2017:19(3):371-80.

11. Brasil. Ministério da Saúde. Secretaria de Atenção À Saúde. Portaria GM № 154, de 24 de janeiro de 2008: Cria os Núcleos de Apoio à Saúde da Família-NASF.Diário Oficial da União, Brasília: Ministério da Saúde, 2008. [Acesso em: 15 de ago.
2016. Disponível em: <http://bvsms.saude.gov. br/bvs/saudelegis/gm/2008/prt0154_24_01_2008. htm>].

12. Sousa MFS, Nascimento CMB, Sousa FBO, Lima MLLT, Silva VL, Rodrigues M. Evolution of speech-language pathologists supply in Unified Health System (SUS) and in primary healthcare in Brazil. Rev. CEFAC. 2017;19(2):213-20.

13. Panizzi M, Lacerda JT, Natal S, Franco TB. Productive restructuring in health: performance and challenges of the Family Health Support Center. Saúde debate [Internet]. 2017 Mar [cited 2017 Sep 08]; 41(112): 155-70. Available from: http://www.scielo.br/scielo.php?script $=$ sci arttext\&pid=S0103-11042017000100155\&Ing $=$ en . http://dx.doi.org/10.1590/0103-1104201711213.

14. Penna GC, Mendes HG, Dias MAS, Souza C, Carvalho LW, Souza DCN et al. Evaluation of the use of videoconferencing for distance training of doctors in the family health teams within the national telehealth project. Rev. méd. Minas Gerais. 2015;25(1):108-14

15. Pacheco SKT, Rios ZM. Telespeech therapy as a continued education strategy in primary health care in the state of Pernambuco, Brazil. Revista Brasileira de Pesquisa em Saúde. 2015;16(4):4-5.

16. Diniz, PRB, Sales, FJR, Novaes MA. Providing telehealth services to a public primary care network: the experience of Rede NUTES in Pernambuco, Brazil. Telemedicine and e-Health. 2016;22(8):694-8.

17. Santos PKT, Rios MZ. A tele-educação no Telessaúde do Estado do Espírito Santo: uma ferramenta importante para qualificação dos profissionais que atuam na Atenção Primária à Saúde. Revista Brasileira de Pesquisa em Saúde.2015;16(4):1-2.

18. Catalani B, De Luccas GR, Berretin-felix G. Tele-education and teleconsultation in oropharyngeal dysphagia: literature review. Distúrb. Comunic. 2017;28(4):83-90.

19. Cruz ELD, Novaes MA, Machiavelli JL, Menezes VA. A characterization of web-conference seminars on the health of adolescents and young people at cyber-health centers in the Brazilian State of Pernambuco. Rev. Bras. Saude Mater. Infant. 2012;12(1): 83-90.

20. Silva MSD, França Junior DB, Martins Júnior JDR, Pinho JRO, Moreira JCR, Oliveira AEFD et al. 2017. Desafios contemporâneos à saúde da criança, 
bases legais de proteção à infância e os principais eixos de atenção integral à saúde da criança no Brasil. [Acesso em 01 set 2017]. Disponível em $<$ https://ares. unasus. gov. br/acervo/handle/ ARES/653>.

21. Oliveira TC, Medeiros WR, Lima KC. Mortality differentials by cause in extreme age groups of elderly. Rev. bras. geriatr. gerontol. [periódico na internet]. 2015 [Acesso em 01 set 2017];18(1):[9 p.]. Disponível em: <http://www.scielo.br/scielo. php? pid $=$ S1809-98232015000100085\&script $=$ sci $_{-}$ abstract\&tlng $=p t>$

22. Sanine PR, Roque CJ. Speech trerapy with elderly people:na experience in center-day. Revista Kairós Gerontologia. 2015;18(2):459-71.

23. Krüger TR. Serviço social e saúde: espaços de atuação a partir do SUS. Serviço Social \& Saúde. 2010;9(2):123-45.

24. Samelli AG, Rondon S, Oliver FC, Junqueira SR, Molini-Avejonas DR. Queixas de fala e linguagem referentes na região ocidental de São Paulo, Brasil. Clinics. 2014;69(6):413-9.

25. Trenche MCB, Biserra MP, Ferreira LP. Interface entre Fonoaudiologia e Educação: análise da produção em periódicos científicos. Distúrb Comun. 2011;23(3)357-63.

26. Brasil. Ministério da Saúde. Ministério da Saúde. Gabinete do Ministro. Núcleo de Apoio à Saúde da Família-Volume 1: Ferramentas para gestão e para o trabalho cotidiano. (Caderno de Atenção básica, 39). Brasília: MS; 2014. [Acesso em 29 set. 2017]. Disponível em: <http://bvsms.saude.gov.br/bvs/ publicacoes/nucleo_apoio_saude_familia_cab39. pdf $>$.

27. Spinardi ACP, Blasca WQ, Wen CL, Maximino LP. Telehealth in Speech-Language Pathology and Hearing: science and technology. Pró-Fono R. Atual. Cient. 2009;21(3):249-54.

28. Godoy SCB, Guimaraes EMP, Assis DSS. Evaluation of the training of nurses in basic health units through telenfermagem. Esc. Anna Nery . 2014;18(1):148-55.

29. De Barros Lucena, BE, Junior, JD, Diniz, RVZ. Telemedicine as support tool for primary health care: a look at teleconsulting in cardiology. Revista Brasileira de Inovação Tecnológica em Saúde (R-BITS). 2015;5(1):13-25.

30. Carneiro NGD, Almeida RCC, Silva RCF, Carvalho MT, Ferreira NM. Integração das Residências de Medicina de Família e Comunidade do Estado de
Pernambuco utilizando Videoconferência. Rev Bras Ciên saúde. 2015;18(3):235-40.

31. Pereira AC. Relato de experiência do apoio do núcleo de Telessaúde da Faculdade de Medicina da Universidade Federal de Minas Gerais para os núcleos de telessaúde do estado do Piauí. Latin American Journal of Telehealth. 2016;3(1)41-50.

32. Cavalini LT. Modelagem do conhecimento em Telessaúde. Jornal Brasileiro de TeleSaúde. 2013;2(4):VI-VII.

33. Silva NA, Santos AMG, Cortez EA, Cordeiro BC. Limits and possibilities of distance learning in continuing education in health: integrative review. Ciênc. saúde coletiva. 2015;20(4):1099-107. 